\title{
PENINGKATAN DAYA SIMPAN IKAN KEMBUNG DENGAN EKSTRAK ETANOLIK Padina sp. SELAMA PENYIMPANAN SUHU KAMAR
}

\section{Enhancing Shelf Life of Mackerel Fillet using Ethanolic Extract of Seaweed Padina sp. During Storage at Room Temperature}

\author{
Amir Husni*, Antarif Kusuma Brata, Siti Ari Budhiyanti \\ Program Studi Teknologi Hasil Perikanan Jurusan Perikanan Fakultas Pertanian, \\ Universitas Gadjah Mada, Jalan Flora Gedung A4 Bulaksumur Yogyakarta \\ ${ }^{\star}$ Korespondensi: a-husni@ugm.ac.id \\ Diterima 10 Januari 2015/Disetujui 20 April 2015
}

\begin{abstract}
Abstrak
Penelitian ini bertujuan untuk menentukan pengaruh penggunaan ekstrak etanolik Padina sp. terhadap daya simpan filet ikan kembung selama penyimpanan pada suhu kamar. Filet ikan kembung direndam selama 30 menit dalam larutan ekstrak etanolik Padina sp. dengan konsentrasi 0; 0,5; 1; 1,5; dan 2 $\mathrm{g} / 100 \mathrm{~mL}$ akuades. Filet ikan kembung kemudian disimpan pada kotak styrofoam pada suhu kamar selama 24 jam dengan selang waktu pengamatan setiap $6 \mathrm{jam}$. Parameter yang diamati meliputi: $\mathrm{pH}$, Total Plate Count (TPC), kadar histamin, kandungan bakteri pembentuk histamin (BPH), dan organoleptik (kenampakan, bau, dan tekstur). Hasil penelitian menunjukkan bahwa penggunaan ekstrak etanolik Padina sp. yang berbeda memberikan pengaruh nyata $(p<0,05)$ terhadap nilai TPC, kandungan $\mathrm{BPH}$, dan nilai organoleptik keseluruhan filet ikan kembung selama 24 jam. Filet ikan kembung yang diberi ekstrak etanolik Padina sp. masih layak konsumsi hingga jam ke-6.
\end{abstract}

Kata kunci: Daya simpan, histamin, ikan kembung, Padina sp.

Abstract

The aim of this research was to determine the effect of Padina sp. ethanolic extract on shelf life of mackerel fillet during storage at room temperature. Mackerel fillet soaked up into Padina sp. extract solution at various concentration $(0 ; 0.5 ; 1 ; 1.5$; and $2 \mathrm{~g} / 100 \mathrm{~mL})$ for 30 minutes and stored in styrofoam box at room temperature for 24 hours. The fillet observed every 6 hours. The observed parameters were $\mathrm{pH}$, total plate count (TPC), total histamine forming bacteria, total histamine, and organoleptic tests. The results showed that the quality parameters of the fillet were significantly affected $(p<0.05)$ by concentration of Padina sp. extract. Total histamine parameter showed that mackerel fillet was safe for consumption until 24 hours of storage time. The treatment of Padina sp. ethanolic extract made mackerel fillet consumable up to 6 hours.

Keywords: Histamine, mackerel, Padina sp., shelf life.

\section{PENDAHULUAN}

Ikan kembung (Rastrelliger sp.) merupakan salah satu jenis ikan laut yang banyak tersedia di Indonesia. Pemanfaatan ikan kembung oleh masyarakat tergolong tinggi, baik untuk dikonsumsi secara langsung maupun sebagai bahan baku produk olahan dan termasuk dalam salah satu bahan kebutuhan pokok penting di Indonesia dalam UU No 7 tahun 2014 (Anonim 2014). Namun demikian ikan kembung memiliki sifat mudah mengalami kerusakan bila tidak ditangani dengan baik. Kerusakan ikan paling utama disebabkan oleh aktivitas bakteri pembusuk (Putro et al. 2008). Indriati et al. (2006) menyebutkan dari beberapa bakteri pembentuk histamin yang terdapat pada produk ikan kembung, Staphylococcus spp. merupakan salah satu bakteri yang paling banyak ditemukan dan berperan aktif dalam terjadinya proses pembentukan senyawa histamin. 
Mangunwardoyo et al. 2007 menyatakan bahwa bakteri Staphylococcus spp. mampu menghasilkan histamin hingga mencapai kadar 124,37 mg sehingga perlu dilakukan penanganan khusus selama masa penyimpanan untuk dapat mempertahankan mutu dan kondisi produk ikan sehingga tetap terjaga kualitas dan keamanannya untuk dikonsumsi.

Beberapa contoh bahan alami telah diketahui memiliki potensi menghambat kemunduran mutu ikan selama penyimpanan, diantaranya alga contohnya Padina sp., Sargassum sp., Gracilaria sp., Caulerpa sp., dan Gelidium sp. yang mengandung beberapa senyawa bioaktif contohnya antibakteri, antivirus dan antitumor (Atmadja, 1992; Salvador et al. 2007; Damirel et al. 2009; Rajasulachana et al. 2009). Penelitian mengenai penggunaan ekstrak alga untuk memperpanjang daya simpan fillet ikan telah dilakukan, contohnya ekstrak Sargassum sp. yang dapat memperpanjang daya simpan fillet nila merah (Wicaksono 2010) dan fillet ikan kembung (Farihah 1993). Selain penggunaan ekstrak Sargassum sp., terdapat juga penelitian mengenai usaha memperpanjang daya simpan fillet nila merah dengan menggunakan ekstrak alga Padina sp. (Husni et al. 2014). Malingin et al. (2012) melaporkan bahwa ekstrak etanolik Padina sp. memiliki aktivitas antibakteri terhadap beberapa bakteri yaitu Staphylococcus aureus, S. pneumoniae, Escherichia coli dan Neisseria gonorrhoeae. Penelitian ini bertujuan menentukan pengaruh penggunaan ekstrak Padina sp. terhadap daya simpan fillet ikan kembung (Rastrelliger sp.) selama penyimpanan suhu kamar.

\section{BAHAN DAN METODE}

\section{Bahan dan Alat}

Bahan yang digunakan dalam penelitian ini terdiri ikan kembung segar yang diperoleh dari pasar TPI Pelabuhan Perikanan Samudera Cilacap dan supermarket Superindo Yogyakarta. Alga Padina sp. didapatkan dari Pantai Drini dan pantai Sepanjang Gunungkidul pada bulan
November 2013. Bahan lain yang digunakan selama penelitian berupa etanol (J.T.Baker), Trypticase Soy Broth (TSB) (Oxoid), Tryptone Soy Agar (TSA) (Oxoid), Plate Count Agar (PCA) (Oxoid), medium Niven agar, metanol (J.T.Baker), resin Dowex, $\mathrm{HCl}$ (J.T.Baker) dan $\mathrm{H}_{3} \mathrm{PO}_{4}$ (J.T.Baker). Peralatan yang digunakan dalam penelitian ini adalah waterbath (Sibata), rotary vacum evaporator (Buchi), freeze dryer, blender, inkubator (Isuzu Incubator Himawari), kolom kromatografi, dan spektrofotometer (Shimadzu).

\section{Ektraksi Padina sp.}

Dalam penelitian ini dilakukan ekstraksi alga Padina sp. untuk mendapatkan ekstrak etanolik. Metode ekstraksi yang digunakan merujuk pada metode ekstraksi Padina sp. menggunakan etanol yang dilakukan Malingin et al. (2012) yang dimodifikasi. Modifikasi dilakukan pada penggunaan suhu evaporasi pada rotary evaporator yang menggunakan suhu $60^{\circ} \mathrm{C}$ dimodifikasi menjadi $40^{\circ} \mathrm{C}$ untuk mengurangi resiko terjadinya kerusakan senyawa yang terkandung dalam alga.

Padina sp. yang sudah dikoleksi dikeringanginkan selama 48 jam dalam ruangan, terhindar dari sinar matahari langsung. Padina sp. yang telah kering kemudian dihancurkan hingga menjadi halus seperti tepung. Sampel sebanyak $1150 \mathrm{~g}$ dimaserasi dengan etanol 95\% sebanyak $3450 \mathrm{~mL}$ selama 24 jam dengan terus digoyang dalam waterbath pada suhu kamar $\left(28-29^{\circ} \mathrm{C}\right)$ pada kecepatan 80-90 rpm. Ekstrak disaring dan residu dimaserasi kembali dengan cara yang sama menggunakan $1150 \mathrm{~mL}$ etanol (setengah volume pelarut awal) selama 24 jam. Filtrat hasil penyaringan kemudian dicampurkan dan dipekatkan dengan rotary evaporator pada suhu $40^{\circ} \mathrm{C}$. Ekstrak pekat yang diperoleh kemudian dikeringkan dengan freeze dryer selama $2 \times 24$ jam. Ekstrak kering yang didapat kemudian ditimbang dan disimpan pada suhu $-20^{\circ} \mathrm{C}$ sampai dilakukan pengujian. 


\section{Penggunaan Ekstrak Etanolik \\ Padina sp. pada Filet Ikan Kembung Selama Penyimpanan dalam Suhu Kamar}

Penggunaan ekstrak etanolik alga Padina sp. yaitu dengan merendam fillet daging ikan kembung ke dalam larutan ekstrak Padina sp. Larutan ekstrak dibuat dengan menambah serbuk ekstrak Padina sp. kedalam akuades dengan variasi konsentrasi $0,0,5$; 1; 1,5; dan $2 \mathrm{~g} / 100 \mathrm{~mL}$ akuades. Fillet ikan kembung seberat $80( \pm 5)$ g yang telah disiapkan kemudian direndam ke dalam $300 \mathrm{~mL}$ ekstrak selama 10 menit. Ulangan dilakukan sebanyak 3 kali. Setelah direndam kemudian ditiriskan selama 15 menit dan simpan dalam dalam styrofoam tertutup dengan pemberian kode konsentrasi terlebih dahulu. Penyimpanan ikan kembung dilakukan pada suhu kamar selama 24 jam. Pengamatan tiap parameter dilakukan setiap 6 jam. Parameter yang diamati meliputi: Uji penentuan $\mathrm{pH}$ menggunakan metode AOAC (1990), penghitungan Total Plate Count (TPC) berdasarkan metode yang ada pada SNI 01-2332.3-2006 (BSN 2006a), penghitungan jumlah bakteri pembentuk histamin (BPH) dilakukan berdasarkan metode Niven et al. (1981), dan penghitungan kadar histamin yang dilakukan berdasarkan pada SNI 2354.10-2009 menggunakan metode spektroflorometri (BSN 2009), serta pengujian organoleptik menggunakan metode skoring yang ditentukan dengan menggunakan scoresheet sesuai SNI 01-2346-2006 (BSN 2006 ${ }^{\mathrm{b}}$.

\section{Analisis Data}

Hasil penelitian dilakukan analisis menggunakan analisis regresi antar perlakuan untuk mengetahui efek perlakuan secara keseluruhan dan untuk mengetahui pengaruh masing-masing perlakuan pemberian ekstrak dibandingkan dengan perlakuan tanpa pemberian ekstrak.

\section{HASIL DAN PEMBAHASAN \\ Ekstrak Padina sp.}

Rendemen yang dihasilkan dari proses ekstraksi Padina sp. sebanyak 3\% dalam bentuk ekstrak kasar (crude extract). Menurut Iswani (2007), persentase rendemen yang dihasilkan dari ekstraksi makroalga dengan menggunakan pelarut etanol berkisar antara 2-3\%. Rendemen yang dihasilkan dari penelitian ini memiliki jumlah yang hampir sama dengan hasil rendemen dari penelitian yang dilakukan Iswani (2007).

\section{Derajat Keasaman (pH)}

Hasil pengujian $\mathrm{pH}$ daging ikan kembung dengan perlakuan ekstrak Padina sp. selama penyimpanan 24 jam suhu kamar dapat dilihat pada Gambar 1. Selama penyimpanan pada suhu kamar, $\mathrm{pH}$ daging ikan kembung dengan perlakuan ekstrak etanolik Padina sp. mengalami penurunan pada jam ke-6. Penurunan nilai $\mathrm{pH}$ pada awal penyimpanan ini disebabkan akibat terbentuknya asam laktat hasil

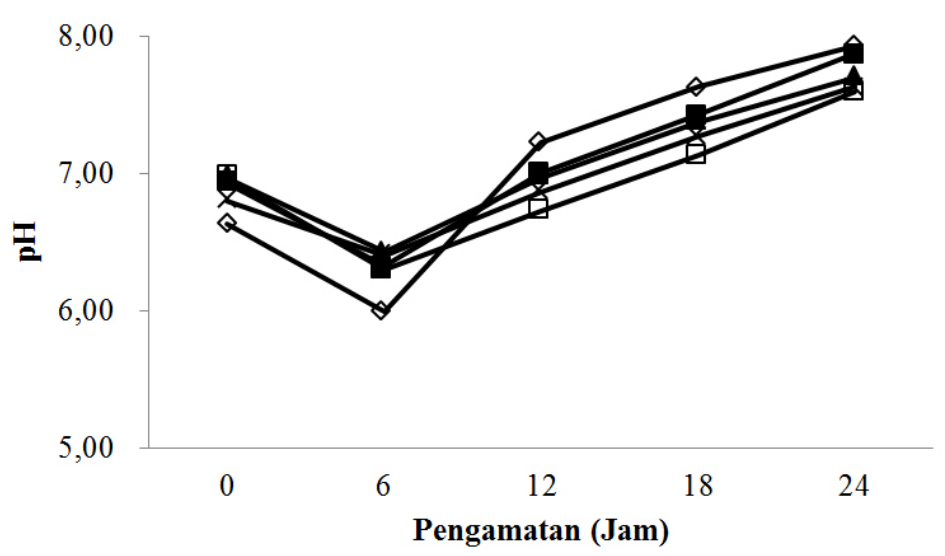

Gambar 1 Pengaruh konsentrasi ekstrak etanolik Padina sp. terhadap pH filet ikan kembung yang disimpan pada suhu kamar $(\diamond=0 ;=0,5 ; \boldsymbol{\Delta}=1 ; \mathrm{X}=1,5 ;$ dan $\square=2 \mathrm{~g} / 100 \mathrm{~mL})$. 
reaksi pemecahan glikogen oleh enzim yang terdapat pada daging (Santoso et al. 1999). Setelah penyimpanan selama jam ke-12 hingga akhir masa penyimpanan (jam ke-24) terjadi kenaikan $\mathrm{pH}$ karena terbentuknya senyawa bersifat basa misalnya amoniak hasil dari proses perombakan protein pada daging ikan oleh enzim dan bakteri (Liviawaty dan Afrianto 2010). Santoso et al. (1999) menambahkan bahwa peningkatan nilai $\mathrm{pH}$ pada daging ikan selama penyimpanan menunjukan adanya aktivitas enzim proteolitik yang terdapat pada jaringan daging ikan sehingga terbentuk senyawa amoniak yang bersifat basa.

Nilai $\mathrm{pH}$ daging ikan kembung yang disimpan pada suhu kamar dengan perlakuan pemberian ekstrak Padina sp. berkisar antara 6,63-6,97 pada awal penyimpanan, kemudian mengalami penurunan pada jam ke- 6 menjadi kisaran antara 6,00-6,43 dan selanjutnya terus mengalami kenaikan sampai kisaran 7,60-7,93 pada jam ke-24. Aprianti (2011) menyatakan bahwa ikan kembung yang disimpan dalam suhu kamar memiliki nilai pH 6,97 pada awal penyimpanan dan pada jam ke-6 mengalami penurunan menjadi 6,72 , kemudian meningkat sampai jam ke-24 menjadi 7,89. Hasil analisis regresi didapatkan bahwa perlakuan pemberian konsentrasi ekstrak etanolik Padina sp. yang berbeda tidak memberikan pengaruh yang berbeda nyata $(p<0,05)$ terhadap $\mathrm{pH}$ pada fillet ikan kembung selama penyimpanan 24 jam pada suhu kamar.

\section{Jumlah Bakteri Total (TPC)}

Hasil pengujian TPC daging ikan kembung dengan perlakuan ekstrak Padina sp. selama penyimpanan suhu kamar dapat dilihat pada Gambar 2. Kandungan total bakteri pada daging ikan kembung semakin meningkat seiring dengan lamanya penyimpanan, namun jumlah bakteri pada fillet ikan kembung yang diberikan perlakuan ekstrak Padina sp. lebih rendah dibandingkan tanpa pemberian ekstrak. Kandungan maksimal bakteri pada ikan untuk dapat dikatakan segar dan layak konsumsi telah diatur dalam SNI 01-2729.1-2006 (BSN $2006^{c}$ ) yaitu 5,0x10 $\mathrm{CFU} / \mathrm{g}$. Hasil penelitian menunjukan fillet ikan yang diberikan perlakuan ekstrak Padina sp. masih layak konsumsi sampai jam ke-6, sedangkan fillet ikan kembung tanpa pemberian ekstrak sudah tidak layak dikonsumsi. Penyimpanan setelah 12 jam hingga akhir masa penyimpanan 24 jam keseluruhan sampel didapatkan sudah tak layak konsumsi. Penelitian Putro et al. (2008) menunjukan bahwa fillet ikan kembung yang disimpan pada suhu kamar dengan pemberian ekstrak bawang putih $2 \mathrm{~g} / 100 \mathrm{~mL}$ akuades sudah tidak layak dikonsumsi pada jam ke-6

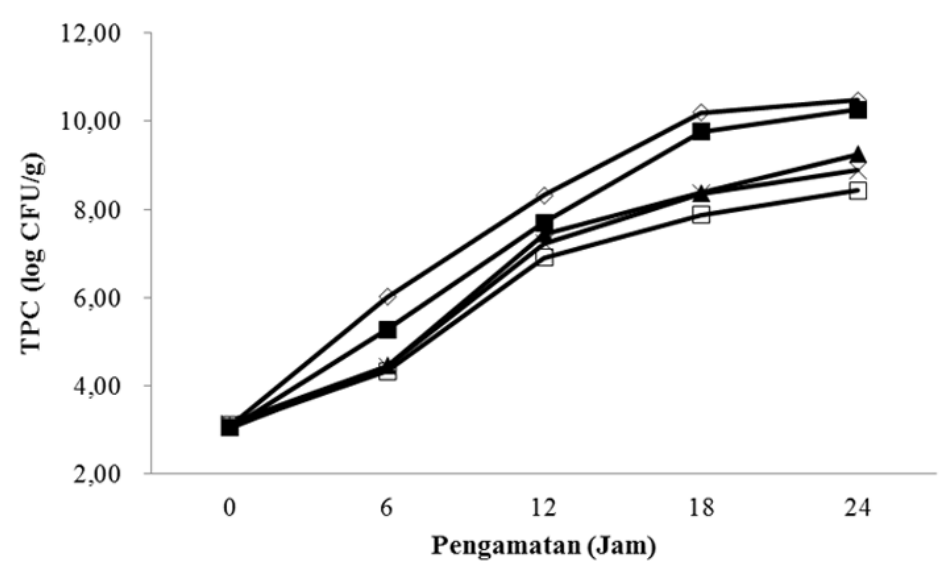

Gambar 2 Pengaruh konsentrasi ekstrak etanolik Padina sp. terhadap jumlah bakteri total (TPC) filet ikan kembung yang disimpan pada suhu kamar $(\diamond=0 ; \mathbf{\boldsymbol { \omega }}=0,5 ; \boldsymbol{\Delta}=1 ; \mathrm{X}=1,5 ;$ dan $\square=2$ $\mathrm{g} / 100 \mathrm{~mL}$ ). 
penyimpanan berdasarkan total kandungan bakterinya.

Berdasarkan hasil analisis regresi didapatkan bahwa perlakuan pemberian konsentrasi ekstrak yang berbeda memberikan pengaruh yang berbeda nyata $(p<0,05)$ terhadap kandungan total bakteri pada fillet ikan kembung selama penyimpanan 24 jam. Perlakuan ekstrak $0 \mathrm{~g} / 100 \mathrm{~mL}$ akuades tidak berbeda nyata dengan perlakuan ekstrak 0,5 $\mathrm{g} / 100 \mathrm{~mL}$ akuades sedangkan perlakuan ekstrak 1, 1,5, dan $2 \mathrm{~g} / 100 \mathrm{~mL}$ akuades berpengaruh nyata pada kandungan total bakteri fillet ikan kembung selama masa penyimpanan 24 jam pada suhu kamar. Pemberian ekstrak etanolik Padina sp., khususnya pada konsentrasi 1, 1,5, dan $2 \mathrm{~g} / 100 \mathrm{~mL}$ akuades mampu menghambat pertumbuhan bakteri dan memperpanjang masa simpan fillet ikan kembung. Peningkatan jumlah bakteri terjadi karena daging ikan merupakan media yang cocok untuk pertumbuhan bakteri, mengingat kandungan protein yang cukup tinggi dari daging ikan itu sendiri. Peningkatan jumlah bakteri selama penyimpanan ini menunjukan penurunan tingkat kesegaran ikan (Liviawaty dan Afrianto 2010). Husni et al. (2013) menunjukkan bahwa aktivitas penghambatan bakteri oleh ekstrak Padina sp. terhadap bakteri pembusuk pada fillet nila merah. Malingin et al. (2012) menyebutkan aktivitas antibakteri pada Padina sp. mayoritas berasal dari senyawa metabolit sekunder dari alga tersebut yaitu senyawa alkaloid, cardiac glycosides, carotenoids, flavonoids, saponins, steroids, tannins dan terpenoids.

\section{Kandungan Bakteri Pembentuk Histamin (BPH)}

Hasil pengujian $\mathrm{BPH}$ fillet ikan kembung dengan perlakuan ekstrak Padina sp. selama penyimpanan suhu kamar dapat dilihat pada Gambar 3. Kandungan total bakteri pada daging ikan kembung semakin meningkat seiring dengan lamanya penyimpanan, namun jumlah bakteri pada fillet ikan kembung yang diberikan perlakuan ekstrak Padina sp. lebih rendah dibandingkan dengan fillet ikan kembung tanpa perlakuan. Ekstrak Padina sp. dapat menghambat pertumbuhan bakteri pembentuk histamin yang terdapatpada fillet ikan kembung.

Jumlah bakteri pembentuk histamin pada waktu awal berkisar antara $3,77 \times 10^{2}$ sampai $5,43 \times 10^{2} \mathrm{CFU} / \mathrm{g}$ dan pada jam ke-24 pada kisaran $2,67 \times 10^{8}$ sampai $2,94 \times 10^{8} \mathrm{CFU} / \mathrm{g}$. Fillet ikan kembung dengan perlakuan pemberian ekstrak Padina sp. $2 \mathrm{~g} / 100 \mathrm{~mL}$ akuades memiliki jumlah bakteripembentuk histamin yang paling rendah, sedangkan jumlah kandungan bakteri pembentuk histamin paling tinggi didapatkan pada fillet ikan tanpa perlakuan ekstrak (kontrol $0 \mathrm{~g} / 100 \mathrm{~mL}$ akuades). Hasil penelitian

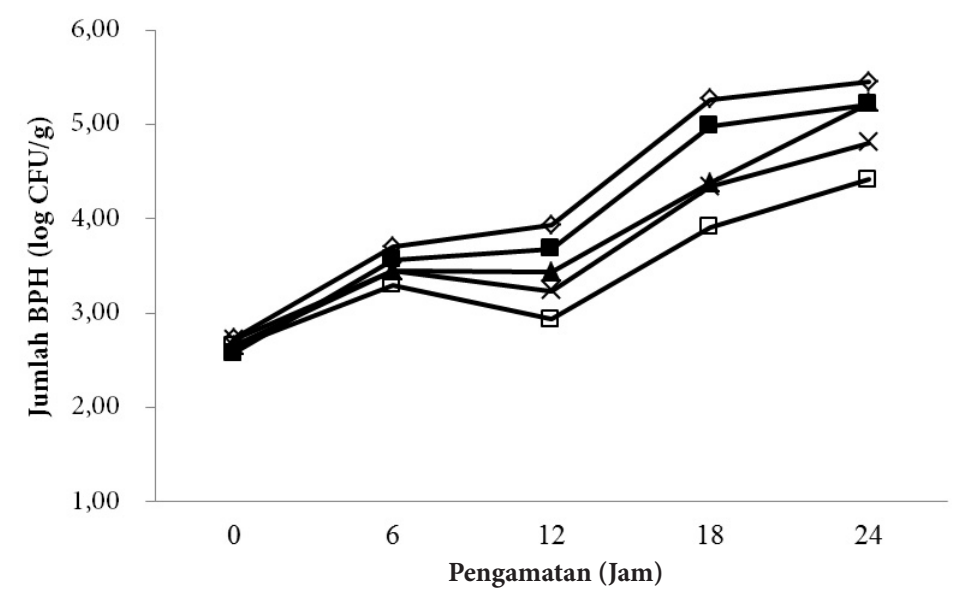

Gambar 3 Pengaruh konsentrasi ekstrak etanolik Padina sp. terhadap jumlah bakteri pembentuk histamin (BPH) ikan kembung yang disimpan pada suhu kamar $(\diamond=0 ; \boldsymbol{\square}=0,5 ; \boldsymbol{\Delta}=1$; $\mathrm{X}=1,5$; dan $\square=2 \mathrm{~g} / 100 \mathrm{~mL}$ ). 
Tabel 1 Pengaruh konsentrasi ekstrak etanolik Padina sp. terhadap kadar histamin $(\mathrm{mg} / \mathrm{kg})$ filet ikan kembung selama penyimpanan pada suhu kamar

\begin{tabular}{lcc}
\hline \multirow{2}{*}{ Perlakuan } & \multicolumn{2}{c}{ Kadar histamin $(\mathrm{mg} / \mathrm{kg})$ pada jam ke- } \\
\cline { 2 - 3 } & 0 & 24 \\
\hline $0 \mathrm{~g} / 100 \mathrm{~mL}$ & $9,09 \pm 0,48$ & $166,83 \pm 0,75$ \\
$0,5 \mathrm{~g} / 100 \mathrm{~mL}$ & $9,26 \pm 1,35$ & $75,41 \pm 0,13$ \\
$1 \mathrm{~g} / 100 \mathrm{~mL}$ & $8,84 \pm 2,27$ & $36,76 \pm 0,25$ \\
$1,5 \mathrm{~g} / 100 \mathrm{~mL}$ & $8,76 \pm 0,12$ & $37,56 \pm 0,27$ \\
$2 \mathrm{~g} / 100 \mathrm{~mL}$ & $9,39 \pm 1,51$ & $24,30 \pm 0,04$ \\
\hline
\end{tabular}

Putro et al. (2008) menunjukan bahwa fillet ikan kembung yang disimpan selama 24 jam pada suhu kamar dengan pemberian ekstrak bawang putih memiliki kisaran jumlah bakteri pembentuk histamin antara $2,9 \times 10^{2} \mathrm{CFU} / \mathrm{g}$ pada awal masa penyimpanan, hingga $2,7 \times 10^{8} \mathrm{CFU} / \mathrm{g}$ setelah 24 jam masa penyimpanan. Pemberian ekstrak Padina sp. pada hasil penelitian ini lebih baik dalam menghambat pertumbuhan bakteri pembentuk histamin pada fillet ikan kembung selama masa 24 jam penyimpanan pada suhu kamar. Berdasarkan hasil analisis regresi didapatkanbahwa pemberian perlakuan ekstrak etanolik Padina sp. yang berbeda memberikan pengaruh beda nyata $(p<0,05)$ terhadap kandungan bakteri pembentuk histamin pada fillet ikan kembung selama penyimpanan 24 jam pada suhu kamar. Perlakuan tanpa pemberian ekstrak etanol dan padina $0,5 \mathrm{~g} / 100$ $\mathrm{mL}$ akuades menunjukkan tidak beda nyata $(p<0,05)$, sedangkan perlakuan pemberian ekstrak 1, 1,5, dan $2 \mathrm{~g} / 100 \mathrm{~mL}$ akuades berpengaruh nyata. Perlakuan pemberian ekstrak etanolik Padina sp., terutama pada konsentrasi 1, 1,5, dan $2 \mathrm{~g} / 100 \mathrm{~mL}$ akuades mampu menghambat pertumbuhan bakteri pembentuk histamin pada fillet ikan kembung.

\section{Kadar Histamin}

Kandungan histamin yang terdapat pada fillet ikan kembung dengan perlakuan ekstrak Padina sp. yang disimpan pada suhu kamar selama 24 jam secara keseluruhan mengalami peningkatan dengan kisaran 24,30-166,83 $\mathrm{mg} / \mathrm{kg}$ daging dibanding dengan kandungan histamin waktu awal penyimpanan yang hanya berkisar antara 8,76-9,39 $\mathrm{mg} / \mathrm{kg}$ daging (Tabel 1). Kandungan maksimum histamin yang diperbolehkan pada daging ikan untuk dikatakan layak dan aman konsumsi sesuai dengan standar SNI 01-2729.1-2006 adalah 100 $\mathrm{mg} / \mathrm{kg}$ daging (BSN 2006 ${ }^{\mathrm{c}}$ ). Dengan demikian dari segi kadar histamine fillet ikan kembung yang diberikan perlakuan ekstrak Padina sp.

Tabel 2 Pengaruh konsentrasi ekstrak etanolik Padina sp. terhadap nilai organoleptik kenampakan filet ikan kembung selama penyimpanan pada suhu kamar

\begin{tabular}{lccccc}
\hline \multirow{2}{*}{ Perlakuan } & \multicolumn{5}{c}{ Nilai organoleptik pada jam ke- } \\
\cline { 2 - 6 } & 0 & 6 & 12 & 18 & 24 \\
\hline $0 \mathrm{~g} / 100 \mathrm{~mL}$ & 7,71 & 7,00 & 4,14 & 3,00 & 1,00 \\
$0,5 \mathrm{~g} / 100 \mathrm{~mL}$ & 7,14 & 7,00 & 4,43 & 3,00 & 1,29 \\
$1 \mathrm{~g} / 100 \mathrm{~mL}$ & 7,71 & 7,00 & 4,43 & 4,14 & 1,86 \\
$1,5 \mathrm{~g} / 100 \mathrm{~mL}$ & 8,00 & 7,29 & 5,00 & 4,14 & 1,86 \\
$2 \mathrm{~g} / 100 \mathrm{~mL}$ & 8,00 & 7,57 & 5,86 & 3,86 & 2,43 \\
\hline
\end{tabular}


masih layak konsumsi hingga penyimpanan 24 jam, sedangkan fillet ikan kembung yang tanpa diberikan ekstrak (kontrol 0 g/ 100 $\mathrm{mL}$ akuades) sudah tidak layak konsumsi.

\section{Organoleptik Kenampakan Daging Ikan Kembung}

Nilai organoleptik kenampakan daging ikan kembung dengan perlakuan ekstrak Padina sp. selama penyimpanan suhu kamar disajikan pada Tabel 2. Nilai organoleptik kenampakan daging ikan kembung pada tiap konsentrasi ekstrak Padina sp. yang digunakan mengalami penurunan seiring dengan lama penyimpanan, yakni skor 7-8 pada awal penyimpanan kemudian menurun hingga skor 1-2 pada akhir penyimpanan. Penurunan nilai organoleptik kenampakan daging ikan kembung pada penyimpanan jam ke-6 masih berkisar pada kondisi layak produk ikan segar, yaitu 7,0. Spesifikasi kenampakan daging ikan kembung pada jam ke-6 yaitu sayatan daging sedikit kurang cemerlang, spesifik jenis, tidak ada pemerahan sepanjang tulang belakang, dinding perut daging utuh (BSN 2006 ${ }^{c}$.

Nilai organoleptik kenampakan daging ikan kembung tanpa perlakuan ekstrak Padina sp. (kontrol $0 \mathrm{~g} / 100 \mathrm{~mL}$ akuades) pada penyimpanan jam ke-24 menunjukan nilai yang terendah bila dibandingkan dengan nilai organoleptik kenampakan daging ikan kembung dengan perlakuan ekstrak Padina sp., sedangkan nilai organoleptik kenampakan yang tertinggi adalah 2,43 pada daging ikan kembung dengan perlakuan ekstrak Padina sp. 2 g/100 mL akuades. Penggunaan ekstrak Padina sp. memberikan pengaruh terhadap kenampakan daging ikan kembung yaitu adanya warna cokelat dan kehijauan pada daging ikan. Warna cokelat dan hijau pada daging ikan kembung tersebut disebabkan oleh warna dominan dari pigmen alga Padina sp. itu sendiri. Salah satu pigmen dominan yang terdapat pada alga cokelat seperti Padina sp. adalah fucoxhanthin yang memberikan warna cokelat (Januar dan Wikanta 2011).

\section{Organoleptik Bau Daging Ikan Kembung}

Nilai organoleptik bau daging ikan kembung dengan perlakuan ekstrak Padina sp. selama penyimpanan pada suhu kamar dapat dilihat pada Tabel 3. Nilai organoleptik bau daging ikan kembung pada tiap konsentrasi ekstrak Padina sp. yang digunakan mengalami penurunan seiring masa penyimpanan, yakni skor 9 pada awal penyimpanan kemudian menurun hingga skor 1-4 di akhir penyimpanan. Penurunan nilai organoleptik bau daging ikan kembung pada masa penyimpanan jam ke-12 berkisar 7,0 untuk daging ikan kembung dengan perlakuan ekstrak Padina sp. konsentrasi 1, 1,5, dan $2 \mathrm{~g} / 100 \mathrm{~mL}$ akuades, namun untuk daging ikan kembung dengan perlakuan ekstrak Padina sp. dengan konsentrasi 0 dan $0,5 \mathrm{~g}$ $100 \mathrm{~mL}$ akuades sudah memiliki nilai

Tabel 3 Pengaruh konsentrasi ekstrak etanolik Padina sp. terhadap nilai organoleptik bau filet ikan kembung selama penyimpanan pada suhu kamar

\begin{tabular}{lccccc}
\hline \multirow{2}{*}{ Perlakuan } & \multicolumn{5}{c}{ Nilai organoleptik pada jam ke- } \\
\cline { 2 - 6 } & 0 & 6 & 12 & 18 & 24 \\
\hline $0 \mathrm{~g} / 100 \mathrm{~mL}$ & 9,00 & 5,86 & 3,86 & 1,00 & 1,00 \\
$0,5 \mathrm{~g} / 100 \mathrm{~mL}$ & 9,00 & 7,57 & 5,00 & 3,00 & 2,14 \\
$1 \mathrm{~g} / 100 \mathrm{~mL}$ & 9,00 & 8,00 & 7,00 & 6,43 & 4,14 \\
$1,5 \mathrm{~g} / 100 \mathrm{~mL}$ & 9,00 & 8,00 & 7,00 & 6,43 & 4,43 \\
$2 \mathrm{~g} / 100 \mathrm{~mL}$ & 9,00 & 8,29 & 7,00 & 6,71 & 4,71 \\
\hline
\end{tabular}


organoleptik di bawah 7,0. Sampel ini telah mengalami penolakan oleh panelis.

Daging ikan kembung dengan perlakuan ekstrak Padina sp. memiliki penurunan nilai organoleptik bau yang lebih kecil dibandingkan dengan penurunan nilai organoleptik yang terjadi kontrol. Daging ikan kembung dengan perlakuan ekstrak Padina sp. memiliki bau khas alga yang menutupi bau dari daging ikan sendiri, sehingga tidak terlalu tercium bau amonia yang menyengat seperti pada daging ikan kembung tanpa perlakuan ekstrak etanolik Padina sp. (kontrol). Hasil penelitian Farihah (1993) menunjukan bahwa nilai organoleptik bau fillet ikan kembung dengan penambahan ekstrak Sargassum sp. yang disimpan selama 24 jam pada suhu kamar mengalami penurunan serupa dengan hasil penelitian ini. Kisaran nilai organoleptik pada awal masa penyimpanan berada sekitar nilai 8 . Penyimpanan setelah 12 jam semua sampel sudah mengalami penolakan dari panelis dengan kisaran nilai organoleptik antara 3-5 pada jam ke-24.

\section{Organoleptik Tekstur Daging Ikan Kembung}

Nilai organoleptik tekstur daging ikan kembung dengan perlakuan ekstrak Padina sp. selama penyimpanan pada suhu kamar dapat dilihat pada Tabel 4. Nilai organoleptik tekstur daging ikan kembung yang diberi ekstrak Padina sp. mengalami penurunan seiring masa penyimpanan, yakni skor 9 pada awal penyimpanan kemudian menurun hingga skor 1-4 di akhir penyimpanan jam ke-24. Penurunan nilai organoleptik tekstur daging ikan kembung pada masa penyimpanan jam ke-6 masih berkisar pada kondisi batas penerimaan oleh panelis, yaitu 7,0 untuk daging ikan kembung dengan perlakuan ekstrak Padina sp. konsentrasi 0,$5 ; 1,0 ; 1,5$; dan $2 \mathrm{~g} / 100 \mathrm{~mL}$ akuades, namun untuk kontrol (0 g/100 mL akuades) sudah mengalami penolakan oleh panelis $($ skor $<7,0)$.

Daging ikan kembung dengan perlakuan ekstrak Padina sp. memiliki penurunan nilai organoleptik tekstur yang lebih kecil dibandingkan dengan penurunan nilai organoleptik yang terjadi pada daging ikan kembung tanpa pemberian ekstrak Padina sp.. Lama penyimpanan jam ke24 didapatkan daging ikan kembung tanpa perlakuan alga memiliki tekstur yang sangat lunak, bekas jari tidak hilang bila ditekan (tidak elastis) dan daging sangat mudah lepas terurai dan hancur, hal tersebut terjadi disebabkan proses degradasi protein oleh bakteri pembusuk (Widiastuti 2008). Daging ikan kembung dengan perlakuan ekstrak Padina sp. memiliki tekstur yang sedikit lebih kompak dibanding dengan daging tanpa perlakuan ekstrak, hal ini menunjukan bahwa ekstrak Padina sp. memiliki pengaruh menghambat aktivitas bakteri, sehingga proses degradasi protein terhambat dan kerusakan tekstur daging dapat lebih dihambat dalam masa penyimpanan pada suhu kamar.

Tabel 4 Pengaruh konsentrasi ekstrak etanolik Padina sp. terhadap nilai organoleptik tekstur filet ikan kembung selama penyimpanan pada suhu kamar

\begin{tabular}{lccccc}
\hline \multirow{2}{*}{ Perlakuan } & \multicolumn{5}{c}{ Nilai organoleptik pada jam ke- } \\
\cline { 2 - 6 } & 0 & 6 & 12 & 18 & 24 \\
\hline $0 \mathrm{~g} / 100 \mathrm{~mL}$ & 9,00 & 6,43 & 4,14 & 1,86 & 1,00 \\
$0,5 \mathrm{~g} / 100 \mathrm{~mL}$ & 9,00 & 7,00 & 5,29 & 3,00 & 1,86 \\
$1 \mathrm{~g} / 100 \mathrm{~mL}$ & 9,00 & 7,00 & 5,00 & 5,00 & 2,43 \\
$1,5 \mathrm{~g} / 100 \mathrm{~mL}$ & 9,00 & 7,00 & 5,00 & 5,00 & 3,29 \\
$2 \mathrm{~g} / 100 \mathrm{~mL}$ & 9,00 & 7,00 & 5,57 & 5,00 & 4,43 \\
\hline
\end{tabular}




\section{KESIMPULAN}

Perlakuan perendaman dalam ekstrak etanolik Padina sp. dapat mempertahankan daya simpan fillet ikan kembung hingga penyimpanan jam ke-6, sedangkan pada sampel tanpa pemberian ekstrak sudah tidak layak dikonsumsi berdasarkan nilai TPC, organoleptik bau, dan organoleptik tekstur. Nilai kandungan bakteri pembentuk histamin dan kandungan histamin pada fillet ikan, ekstrak Padina sp. mampu menghambat pertumbuhan bakteri yang dapat menyebabkan penurunan mutu daging dan juga pembentukan senyawa histamin pada fillet ikan kembung yang dapat berbahaya bagi manusia bila dikonsumsi pada jumlah yang melebihi ambang batas tertentu.

\section{UCAPAN TERIMA KASIH}

Penelitian ini dapat terlaksana berkat dukungan dana dari Fakultas Pertanian Universitas Gadjah Mada melalui skema Hibah Penelitian Fakultas Pertanian UGM Tahun Anggaran 2013.

\section{DAFTAR PUSTAKA}

Anonim. 2014. 18 Barang yang masuk kebutuhan pokok di UU perdagangan. Pada: http:// www.gatra.com/ekonomi-1/50062-18barang-ini-masuk-kebutuhan-pokok-di-uuperdagangan.htmL. Diakses pada : 12 April 2014 pukul 18.35.

[AOAC] Association of Official Analytical Chemyst. 1990. Official Method of Analysis of The Association of Official Analytical of Chemist. Arlington, Virginia (USA): Published by The Association of Official Analytical Chemist. Inc..

Aprianti D. 2011. Aktivitas antibakteri ekstrak biji picung (Pangium edule Reinw) dan pengaruhnya terhadap stabilitas fisiko kimia, mikrobiologi dan sensori ikan kembung. [Skripsi]. Jakarta: Fakultas Sains dan Teknologi. Universitas Islam Negeri Syarif Hidayatullah.

Atmadja WS. 1992. Alga sebagai obat. Jurnal Oseana 17:1-8

.[BSN] Badan Standardisasi Nasional. 2006a. Cara
Uji Mikrobiologi. Penentuan Angka Lempeng Total (ALT) pada Produk Perikanan. SNI 01.2332.3-2006. Jakarta: Badan Standardisasi Nasional Indonesia.

[BSN] Badan Standardisasi Nasional. 2006b. Petunjuk Pengujian Organoleptik atau Sensori. SNI 01.2346-2006. Jakarta: Badan Standardisasi Nasional Indonesia.

[BSN] Badan Standardisasi Nasional. 2006c. Ikan Segar-Bagian 1: Spesifikasi. SNI 01.2729.12006. Jakarta: Badan Standardisasi Nasional Indonesia.

[BSN] Badan Standardisasi Nasional. 2009. Pengujian Kadar Histamin pada Produk Perikanan menggunakan Metode Spektroflorometridan HPLC. SNI 2354.102009. Jakarta: Badan Standardisasi Nasional Indonesia.

Demirel Z, Yilamz-Koz FF, Karabay-Yavasoglul UN, Ozdemir G, Sukatar A. 2009. Antimicrobial and antioxidant activity of brown algae from the aegean sea. Journal Serbia Chemical Society 4:7-15.

Farihah I. 1993. Ekstraksi zat antibakteri dari Sargassum sp. dan aplikasinya sebagai zat pengawet fillet ikan kembung (Rastrelliger sp.). [Skripsi]. Bogor: Program Studi Pengolahan Hasil Perikanan. Fakultas Perikanan. Institut Pertanian Bogor.

FDA. 2001. Fish and fisheries product hazards andcontrols guidance. 3rd ed. U.S. FDA. Center for FoodSafety and Applied Nutrition, Maryland.

Husni A, Ustadi, Hakim A. 2013. Penggunaan ekstrak alga Padina sp. untuk peningkatan daya simpan fillet nila merah yang disimpan pada suhu dingin. Agritech 34: 239-246.

Indriati N, Rispayeni, Heruwati E.S. 2006. Studi bakteri pembentuk histamin pada ikan kembung peda selama proses pengolahan. Jurnal Pascapanen dan Bioteknologi Kelautan dan Perikanan 1: 117 - 124.

Irmawan S. 2009. Status perikanan ikan kembung di Kabupaten Barru. Laporan Penelitian. Fakultas Perikanan dan Ilmu Kelautan, Universitas Brawijaya Malang.

Iswani S. 2007. Proses preparasi ekstrak kasar 
(crude extract) etanol dari makroalga untuk uji farmakologi. Buletin Teknik Litkayasa Akuakultur 6:57-60.

Januar HI, Wikanta T. 2011. Korelasi kandungan fukosantin dari Turbinaria sp. terhadap nutrien laut di Pantai Binuangeun dan Krakal. Squaleen 6(1): 19-25.

Ko IS. 2006. Factors affecting histamine level in Indonesian canned Albacore Tuna (Thunnus alalunga). [Thesis]. Norwegia: Departement of Marine Biotechnology. Norwegian College of Fishery Science, University of Tromso.

Liviawaty E, Afrianto E. 2010. Penanganan Ikan Segar, Proses Penurunan dan Cara Mempertahankan Kesegaran Ikan. Bandung: Widya Padjajaran.

Malingin DL, Hongayo MC, Larino RC. 2012. Antibacterial and antioxidant effects of brown alga Padina australis Hauck crude extract. International Journal of Science and Clinical Laboratory 2:35-70.

Mangunwardoyo W, Shopia RA, Heruwati ES. 2007. Seleksi dan pengujian aktivitas enzim L-Histidine decarboxylase dari bakteri pembentuk histamin. Jurnal Makara Sains 11:104-109.

NivenCF, JeffreyMB, Corlett,DA. 1981.Differential planting medium for quantitative detection of histamine-forming bacteria. Application and
Enviroment Microbiology 41(1):321-322.

Putro S, Dwiyitno, Hidayat JF, Pandjaitan M. 2008. Aplikasi ekstrak bawang putih (Alium sativum) untuk memperpanjang daya simpan ikan kembung segar (Rastrelliger kanagurta). Jurnal Pascapanen dan Bioteknologi Kelautan dan Perikanan 3(2):194-200.

RajasulochanaP,Dhamotharan R, Krishnamoorthy P, Murugesan S. 2009. Antibacterial activity of the extract of marine red and brown algae. Journal of American Science 5:20-25.

Santoso J, Nurjanah, Sukarno, Sinaga SR. 1999. Kemunduran mutu ikan nila merah (Oreochromis sp.) selama penyimpanan pada suhu chilling. Buletin Teknologi Hasil Perikanan 4:1-4.

Salvador N, Garreta AG, Lavelli L, Ribera M. 2007. Antimicrobial activity of Iberian macroalgae. Scientia Marina 71: 101-113.

Wicaksono AA. 2007. Pengaruh Ekstrak Sargassum sp. terhadap Daya Awet Fillet Nila Merah (Oreochromis niloticus) pada Penyimpanan Dingin. Jurusan Perikanan. [Skripsi]. Bogor: Fakultas Pertanian. Universitas Gadjah Mada.

Widiastuti I. 2008. Analisis mutu ikan tuna selama lepas tangkap pada perbedaan preparasi dan waktu penyimpanan. [Tesis]. Bogor: Sekolah Pascasarjana. Institut Pertanian Bogor. 